\title{
STRATEGI PENGEMBANGAN OBJEK WISATA ALAM CURUG NGELAY DESA BAGAWAT KECAMATAN SELAJAMBE KABUPATEN KUNINGAN
}

\author{
Sahidin'), Nina Herlina ${ }^{2)}$, Nurdin ${ }^{3)}$ \\ ${ }^{1}$ Program Studi Kehutanan, Fakultas Kehutanan, Universitas Kuningan \\ email: sahidin01@gmail.com \\ ${ }^{2}$ Program Studi Kehutanan, Fakultas Kehutanan, Universitas Kuningan \\ email: nina.herlina@uniku.ac.id \\ ${ }^{3}$ Program Studi Kehutanan, Fakultas Kehutanan, Universitas Kuningan \\ email: nurdin@uniku.ac.id
}

\begin{abstract}
Abstrak: Indonesia merupakan negara yang memiliki keanekaragaman budaya dan sumber daya alam. Salah satu kekayaan yang dimiliki Indonesia adalah ditemukannya berbagai macam tempat wisata alam dengan pesona dan ciri khas tersendiri. Kabupaten Kuningan memiliki tempat-tempat yang berpotensi menjadi destinasi wisata alam yang sangat menarik untuk dikunjungi. Salah satu tempat wisata alam yang ada di Kabupaten Kuningan adalah Curug Ngelay yang berada di Desa Bagawat, Kecamatan Selajambe. Kondisi Curug Ngelay saat ini masih membutuhkan pengelolaan yang baik. Tujuan dari penelitian ini adalah untuk mengetahui potensi yang dimiliki oleh Objek Wisata Alam Curug Ngelay dan strategi dalam mengembangkan Objek Wisata Alam Curug Ngelay dengan potensi yang ada. Penelitian ini dilaksanakan pada bulan November 2017 sampai dengan Januari 2018. Metode yang digunakan dalam penelitian ini untuk mengetahui potensi adalah metode eksplorasi sedangkan untuk pengembangan strategi pengembangan menggunakan analisis SWOT. Hasil penelitian menunjukkan potensi yang dimiliki oleh Objek Wisata Alam Curug Ngelay yaitu keberadaan keindahan alam, Curug Ngelay, serta Flora dan Fauna. Posisi pembangunan berada pada kuadran I. Strategi pembangunan yang diterapkan adalah dengan meningkatkan kualitas dan infrastruktur, meningkatkan kerjasama dengan masyarakat, kerjasama antara pengelola dengan masyarakat dan pengunjung.
\end{abstract}

Kata Kunci: Strategi; Faktor Internal dan Eksternal; Analisis SWOT; Kawasan Wisata

\section{PENDAHULUAN}

Indonesia merupakan sebuah negara yang mempunyai berbagai ragam kebudayaan dan sumber daya alam yang merupakan modal utama untuk meningkatkan taraf hidup bangsa melalui pendayagunaan kekayaan yang dimiliki. Salah satu kekayaan yang dimiliki Indonesia adalah ditemukannya berbagai macam tempat objek wisata dengan daya tarik dan ciri khas tersendiri, sehingga dapat menarik perhatian para wisatawan baik domestik maupun mancanegara untuk berkunjung ke Negara Indonesia (Sari, 2009). Pemerintah berusaha keras membuat rencana dan berbagai kebijakan yang mendukung kearah kemajuan pariwisata. Salah satu kebijakan tersebut adalah menggali, menginventarisir dan mengembangkan obyek-obyek wisata yang ada sebagai daya tarik utama bagi wisatawan. (Asriandy, 2016).
Kabupaten Kuningan memiliki tempat-tempat yang berpotensi menjadi destinasi wisata alam yang sangat menarik untuk dikunjungi. Salah satu wisata alam yang berada di Kabupaten Kuningan adalah Curug Ngelay, tepatnya berada di Desa Bagawat, Kecamatan Selajambe. Obyek Wisata Alam Curug Ngelay pengelolaanya dilakukan oleh warga di sekitar kawasan Obyek Wisata Alam Curug Ngelay yang pegawasannya di bawah pemerintah setempat dan perhutani. Hasil survey awal, selain terdapat air terjun di sekitar kawasan Obyek Wisata Alam Curug Ngelay terdapat pemandangan sangat indah, udara yang sejuk dan beberapa satwa liar.

Obyek Wisata Alam Curug Ngelay saat ini masih perlu pengelolaan dengan baik, seperti penyediaan sarana dan prasarana yang masih minim, tidak tersedianya air bersih untuk MCK, tidak adanya tempat peristiharatan yang disediakan bagi pengunjung untuk menikmati keindahan alam Curug Ngelay. 
Melihat permasalahan tersebut peneliti bermaksud mengetahui upaya yang di lakukan pihak pengelola dalam mengembangkan dan meningkatkan jumlah pengunjung di Objek Wisata Alam Curug Ngelay.

Adapun rumusan masalah dari penelitian ini adalah bagaimana potensi Obyek Wisata Alam Curug Ngelay ? strategi apa yang harus dilakukan oleh pihak pengelola dalam mengembangkan Obyek Wisata Alam Curug Ngelay dengan potensi yang ada?. Dengan tujuan penelitian untuk mengetahui potensi yang dimiliki oleh Obyek Wisata Alam Curug Ngelay, untuk mengetahui strategi apa yang harus dilakukan oleh pihak pengelola dalam mengembangkan Objek Wisata Alam Curug Ngelay dengan potensi yang ada.

\section{METODOLOGI PENELITIAN}

Penelitian ini dilakukan di Obyek Wisata Alam Curug Ngelay Desa Bagawat Kecamatan Selajambe Kabupaten kuningan. Waktu penelitian mulai dari bulan November tahun 2017 sampai bulan Januari tahun 2018.

Alat yang digunakan dalam penelitian ini yaitu: kuisioner, alat tulis, kamera dan komputer

Jenis dan Sumber Data

1. Data primer yaitu data yang diperoleh secara langsung di lapangan dari objek penelitian melalui observasi seperti potensi kawasan, promosi, potensi,alam, aksesibilitas, sarana dan prasarana

2. Data sekunder adalah data yang diperoleh dengan berdasarkan acuan materi atau literatur dan review terhadap dokumen, buku, bahan bacaan, laporan, dan peraturan perundangan yang berhubungan dengan permasalahan yang diteliti.

Pengumpulan data yang dilakukan untuk penyusunan Strategi Pengembangan Obyek Wisata Alam Curug Ngelay dibedakan menjadi dua yaitu : Potensi Wisata dan Potensi Pengunjung :

1. Potensi Wisata: Budaya masyarakat, vegetasi dan satwayang berada di sekitar kawasan Obyek Wisata Alam Curug Ngelay. Untuk mengetahui budaya masyarakat hanya menggunakan metode wawancara, sedangkan untuk mengetahui vegetasi dan satwa menggunakan metode wawancara dan jelajah.
2. Potensi Permintaan Wisata: Wisatawan atau pengunjung, masyarakat lokal yang terlibat dalam pengembangan Obyek Wisata Alam Curug Ngelay. Metode yang digunakan untuk mengetahui petensi permintaan wisata yaitu :

a) Metode survey (field survey), yaitu pengumpulan data yang dilakukan melalui metode observasi, (kuisioner dan wawancara). (Flamin dan Asnaryati 2013)

b) Metode dokumentasi, merupakan teknik pengumpulan data dengan mengabadikan sumber-sumber di lapangan yang berkaitan dengan permasalahan yang sedang diteliti atau dari hasil publikasi lembaga-lembaga atau instansi pemerintah dan organisasi lainnya. (Flamin dan Asnaryati 2013)

c) Studi kepustakaan merupakan cara untuk mengumpulkan data dengan menggunakan dan mempelajari literatur buku-buku kepustakaan yang ada untuk mencari konsepsi-konsepsi dan teori-teori yang berhubungan dengan permasalahan. (Asriandy 2016).

\section{Pengambilan Sampel Dan Analisis Data Pengambilan Sampel}

Pengambilan sampel untuk pengelola Obyek Wisata Alam Curug Ngelay dengan menggunakan metode Sampling Jenuh (sampling sensus). Sampling Jenuh adalah teknik penentuan sampel apabila semua anggota populasi digunakan sebagai sampel (Sugiyono, 2012)

Pengambilan sampel untuk masyarakatmengunakan metode Purposive Sampling yakni teknik pengambilan sampel secara sengaja, dengan menentukan kriteria yang sesuai dengan tujuan penelitian. Kriteria yang ditentukan yaitu responden harus berusia minimal 18 tahun dan tidak lebih dari 60 tahun, masyarakat yang terlibat dalam pengelolaan serta masyarakat sekitar kawasan Pengambilan sampel untuk pengunjung menggunakan metode Simple Random Sampling. Simpel Random Sampling merupakan teknik pengambilan anggota sampel dari populasi yang dilakukan secara acak tanpa memperhatikan strata yang ada dalam populasi. Sampel pengunjung yang 
diambil merupakan $10 \%$ dari jumlah total pengunjung bulanan yang biasanya mencapai 100 pengunjung (Sugiyono, 2012)

Penentuan ukuran sampel pengunjung dan masyarakat menggunakan rumus Slovin (Sugiyono 2013) :

$$
n=\frac{N}{1+N(e)^{2}}
$$

Keterangan :

$\mathrm{n}$ : Ukuran sampel

$\mathrm{N}$ : Ukuran populasi pengunjung

e : Nilai Kritis atau Batas Ketelitian

Nilai kritis atau batas ketelitian yang dipergunakan untuk populasi adalah 10\% $(0,1)$. Populasi masyarakat sebesar 1.447 jiwa (jumlah penduduk Desa Bagawat tahun 2016).

\section{a. Jumlah sampel wisatawan}

Pengambilan sampel untuk pengunjung ditentukan dari rata-rata jumlah pengunjung perbulan.

$$
\begin{aligned}
\mathrm{n}=\frac{N}{1+N(e)^{2}} & =\frac{100}{1+100(0,1)^{2}} \\
& =\frac{100}{2}=50
\end{aligned}
$$

b. Jumlah sampel masyarakat sekitar Obyek Wisata Alam Curug Ngelay

$$
\begin{aligned}
\mathrm{n}=\frac{N}{1+N(e)^{2}} & =\frac{1.447}{1+1.447(0,1)^{2}} \\
& =\frac{1.447}{15.47}=94
\end{aligned}
$$

\section{Analisis Data}

Analisis data dilakukan dengan menggunakan metode analisis SWOT. Analisis SWOT (Strenghts, Weaknesses Opportunities, Threats) yaitu metode yang digunakan untuk menentukan strategi pengembangan dari faktor kekuatan, peluang, kelemahan, dan ancaman terhadap kondisi yang ada pada Obyek Wisata, Juankhan (2008) ) dalam Flamin dan Asnaryati (2013). Alat yang dipakai dalam metode analisis SWOT yaitu dengan menggunakan matriks SWOT. Matrik ini akan menggambarkan secara jelas tentang bagaimana peluang dan ancaman eksternal yang dihadapi dapat disesuaikan dengan kekuatan dan kelemahan internal yang dimiliki. Yang dapat dilihat pada matriks perumusan strategi analisis SWOT pada tabel dibawah.

\begin{tabular}{lll}
\hline Matrik Analisis SWOT & Strength $(\mathbf{S})$ & Weakness $(\mathbf{W})$ \\
\cline { 2 - 3 } & Menentukan 5-10 & Menentukan 5-10 \\
& Faktor kekuatan internal & Faktor kelemahan internal \\
\cline { 2 - 3 } Opportunity(O) & Starategi (SO) & Strategi (WO) \\
Menentukan 5-10 & Ciptakan strategi yang & Ciptakan straegi meminimalkan \\
Menentukan faktor peluang & menggunakan kekuatan untuk & kelemahan untuk memanfaatkan \\
Eksternal & memanfaatkan peluang & peluang \\
Threat (T) & Strategi (ST) & Strategi (WT) \\
Menentukan 5-10 & Ciptakan strategi yang & Ciptakan strategi yang \\
Menentukan faktor ancaman & menggunakan kekuatan untuk & meminimalkan kelemahan dan \\
Eksternal & mengatasi ancaman & menghindari ancaman \\
\hline
\end{tabular}

Sumber : Rangkuty 2002.

\section{Penentuan Pembobotan}

Menentukan nilai analisis SWOT dilakukan dengan pembobotan dari hasil penyebaran kuisioner yang diberikan kepada pengunjung, pengelola, dan masyarakat sekitar. Pembobotan tersebut yaitu : Hasil kuisioner yang diberikan kepada pengunjung yang bersifat kualitatif di kuantitatifkan dengan skala mulai dari 4 (sangat penting), sampai 1 (tidak penting). Setelah seluruh hasil kuisioner dihitung kemudian dilanjutkan dengan mengidentifikasi faktor-faktor strategis internal dan eksternal kawasan 
Obyek Wisata Alam Curug Ngelay, dengan menggunakan metode pembobotan (skoring).

\section{Matrik Faktor Internal dan Eksternal}

Setelah penghitungan pembobotan selesai dilakukan selanjutnya membuat faktor strategi eksternal dan internal, dengan langkah sebagai berikut:

1) Menentukan faktor - faktor yang menjadi kekuatan serta kelemahan yang terdapat di Kawasan Obyek Wisata Alam Curug Ngelay dalam kolom 1.

2) Memberi bobot masing - masing faktor tersebut dengan skala dari 1,0 (paling penting) sampai 0,0 (tidak penting), berdasarkan pengaruh faktor-faktor tersebut terhadap posisi strategis di Obyek

\begin{tabular}{|c|c|c|c|}
\hline $\begin{array}{c}\text { Faktor } \\
\text { internal/Eksternal }\end{array}$ & Bobot & Rating & Skor Pembobotan \\
\hline \multicolumn{4}{|l|}{ Kekuatan/Peluang } \\
\hline \multicolumn{4}{|l|}{ Jumlah S/O } \\
\hline \multicolumn{4}{|l|}{ Kelemahan/Ancaman } \\
\hline \multicolumn{4}{|l|}{ Jumlah W/T } \\
\hline Jumlah $\mathrm{S}+\mathrm{W} / \mathrm{O}+\mathrm{T}$ & & & \\
\hline
\end{tabular}

Wisata Alam Curug Ngelay. Semua bobot tersebut jumlahnya tidak lebih dari satu berdasarkan pengaruh dan kondisi Kawasan Obyek Wisata Alam Curug Ngelay.

3) Menentukan rating, variabel yang bersifat positif (semua yang masuk kategori kekuatan dan peluang) diberi nilai mulai dari +1 sampai dengan +3 (sangat baik), untuk variabel yang bersifat negatif adalah sebaliknya.

4) Kalikan bobot pada kolom 2 dengan rating pada kolom 3 .

5) Jumlahkan skor pembobotan untuk memperoleh total skor
Penskoringan atau pembobotan ini dilakukan untuk mendapatkan posisi strategi pengembangan Objek Wisata Alam Curug
Ngelay pada diagram Analisis SWOT. Diagram SWOT dapat dilihat pada Matrik Grand Strategi yang ada di Gambar berikut.

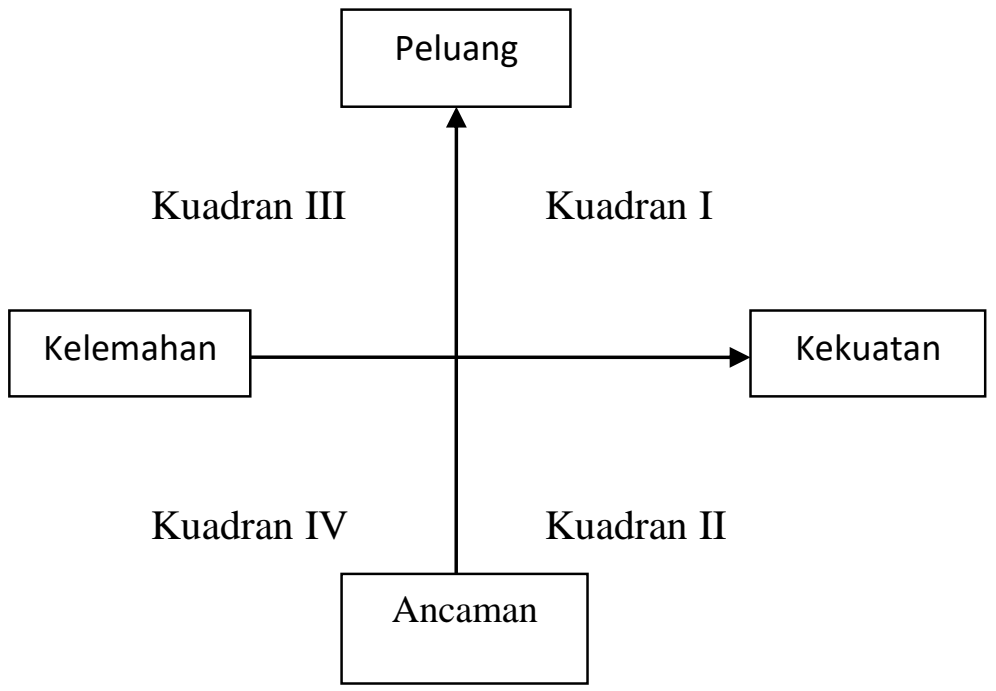

Keterangan Gambar:

1. Kuadran I : Strategi ini dibuat dengan memanfaatkan seluruh kekuatan yang berada di Objek Wisata Alam Curug Ngelay untuk memanfaatkan peluang sebesar-besarnya.
2. Kuadran II : Ini adalah strategi dalam menggunakan kekuatan yang dimiliki untuk mengatasi ancaman.

3. Kuadran III : Strategi ini diterapkan berdasarkan pemanfaatan peluang yang ada dengan cara meminimalkan kelemahan yang ada. 
4. Kuadran IV : Strategi ini didasarkan pada kegiatan yang bersifat defensif dan berusaha meminimalkan kelemahan yang ada serta menghindari ancam

\section{HASIL DAN PEMBAHASAN \\ Potensi Wisata}

Potensi wisata merupakan syarat penting yang dimiliki suatu kawasan obyek wisata, karena potensi yang terdapat dalam kawasan obyek wisata dapat berbeda di setiap tempat, semakin unik dan indah potensi yang terdapat di suatu kawasan wisata maka wisatawan akan semakin tertarik untuk mejadikan tempat tersbut sebagai suatu destinasi wisata.

\section{Bentang Alam}

Panorama alam di sekitar kawasan Obyak Wisata Alam Curug Ngelay menjadi daya tarik bagi wisatawan. Jika memasuki Kawasan Obyek Wisata Alam Curug Ngelay, maka wisatawan akan disuguhkan dengan hamparan sawah dan hembusan angin yang sejuk

\section{Curug Ngelay}

Perjalanan ke Curug Ngelay dapat di tempuh dengan berjalan kaki \pm 45 menit dari loket pembayaran tiket. Curug ngelay merupakan obyek utama yang menjadi tujuan wisatawan. Ketinggian Curug (air terjun) mencapai $\pm 70 \mathrm{~m}$ menjadikan kawasan Obyek Wisata Alam Curug Ngelay cocok untuk dijadikan destinasi wisata bagi wisatawan yang menyukai wisata air terjun.

\section{Flora}

Berdasarkan hasil observasi di lapangan jenis Flora dan Fauna yang ditemukan di sekitar Kawasan Obyek Wisata Alam Curug Ngelay terdapat 7 jenis Flora.

\begin{tabular}{lll}
\hline No & Nama Jenis & Nama Ilmiah \\
\hline 1 & Mahoni & Swietenia Mahagoni \\
2 & Salam & Syzygium polyanthum \\
3 & Jati & Tectona grandis \\
4 & BambuBitung & Bambuseae \\
5 & Kemiri & Aleurites moluccanus \\
6 & Duren & Durio Zibentinus \\
7 & Kaliandra & Calliandracalothyrsus \\
\hline
\end{tabular}

Fauna

Berdasarkan hasil observasi di lapangan jenis Flora dan Fauna yang ditemukan di sekitar
Kawasan Obyek Wisata Alam Curug Ngelay $\begin{array}{llll}\text { terdapat } & 7 & \text { jenis } & \text { Fauna }\end{array}$

\begin{tabular}{lll}
\hline No & Nama Jenis & Nama Ilmiah \\
\hline 1 & Kupu-kupu Belerang & EuremaBlanda \\
2 & Burung kutilang & Pycnonotusaurigaster \\
3 & Burung sepah madu & Aethopygasiparaja \\
4 & Ular Sawah & Hypsiscopusplumbea \\
5 & Kadal & Eutropismultifasciata \\
6 & Katak sawah & Fejervaryacancrivora \\
7 & Monyet ekor panjang & Macacafascicularis \\
\hline
\end{tabular}

Strategi Pengembangan Obyek Wisata Alam Curug Ngelay

Strategi pengembangan Obyek wisata Alam Curug Ngelay dirumuskan melalui analisis SWOT yang meliputi faktor internal yaitu terdapat 6 kekuatan dan 6 kelemahan serta faktor eksternal terdapat 3 peluang dan 3 ancaman yang dihasilkan dari pengamatan langsung dilapangan, kuisioner kepada pengunjung, serta wawancara kepada pengelola dan masyarakat sekitar.

Faktor Internal (Kekuatan dan
Kelemahan)
Kekuatan
1. Keberadaan potensi
2. Keamanan
3. Ketersediaan tempat parkir
4. Ketersediaan MCK


5. Ketersediaan Mushola

6. Ketersediaan kantin

\section{Kelemahan}

1. Modal

2. Kondisi Jalan

3. Sarana Wisata

4. Sumber Daya Manusia

5. Kegiatan Pemasaran Belum Maksimal

6. Kurangnya Ketersediaan Tempat Sampah

\section{Faktor Eksternal (Peluang dan Ancaman)}

\section{Peluang}

1. Meningkatnya Pendapatan Daerah

2. Dukungan Masyarakat Sekitar

3. Penambahan Fasilitas

\section{Ancaman}

1. Pencemaran Lingkungan

2. Konflik Sosial Masyarakat

3. Bencana Alam

\section{Analisis Matrik Faktor Internal dan Eksternal}

Setelah faktor-faktor strategis internal dan eksternal teridentifikasi maka dibuatlah tabel IFAS (Internal Factors Analysis Summary) untuk merumuskan faktor-faktor strategi internal dalam kerangka Strengths dan Weaknesses serta tabel EFAS (EksternalFactors Analysis Summary) untuk merumuskann faktor-faktor strategi eksternal dalam kerangka Opportunities dan Threats

\begin{tabular}{llccc}
\hline No & Fakor Internal & B & R & S \\
\hline \multicolumn{2}{c}{ Kekuatan $($ Strength/S) } & & & \\
1 & Keberadaan potensi & 0,11 & 4 & 0,44 \\
2 & Keamanan & 0,10 & 3 & 0,30 \\
3 & Ketersediaan tempat parkir & 0,08 & 3 & 0,24 \\
4 & Ketersediaan MCK & 0,08 & 3 & 0,24 \\
5 & Ketersediaan Mushola & 0,08 & 3 & 0,24 \\
$6 \quad$ Ketersediaan kantin & 0,06 & 2 & 0,12 \\
Jumlah S & & & 1,58 \\
Kelemahan (Weakness/W) & & & \\
\hline 1 & Modal & 0,10 & 2 & 0,20 \\
2 & Kondisi Jalan & 0,10 & 1 & 0,10 \\
3 & Sarana Wisata & 0,10 & 2 & 0,20 \\
4 & Sumber Daya Manusia & 0,08 & 2 & 0,16 \\
5 & Kegiatan Pemasaran Belum Maksimal & 0,08 & 2 & 0,16 \\
6 & Kurangnya Ketersediaan Tempat Sampah & 0,03 & 1 & 0,03 \\
Jumlah W & & & 0,55 \\
& & & &
\end{tabular}

\begin{tabular}{clccc}
\hline No $\quad$ Faktor Eksternal & B & R & S \\
\hline Peluang (Opportunities/O) & & & \\
$1 \quad$ Meningkatnya Pendapatan Daerah & 0,18 & 2 & 0,36 \\
$2 \quad$ Dukungan Masyarakat Sekitar & 0,18 & 3 & 0,54 \\
$3 \quad$ Penambahan Fasilitas & 0,18 & 3 & 0,54 \\
Jumlah O & & & 1,44 \\
Ancaman (Threats/T) & & & \\
\hline $1 \quad$ Pencemaran Lingkungan & 0,14 & 2 & 0,28 \\
$2 \quad$ Konflik Sosial Masyarakat & 0,14 & 3 & 0,28 \\
$3 \quad$ Bencana Alam & 0,18 & 2 & 0,36 \\
Jumlah T & & & 0,92
\end{tabular}

$\mathbf{O}+\mathbf{T}=\mathbf{2 , 3 6}$

Berdasarkan tabel diatas dapat diketahui pada faktor eksternal adalah (Y) bernilai bahwa skor untuk faktor internal adalah (X) (2,36), maka Obyek Wisata Alam Curug bernilai $(2,13)$ dan skor yang paling tinggi Ngelay berada pada posisi kuadran I. 


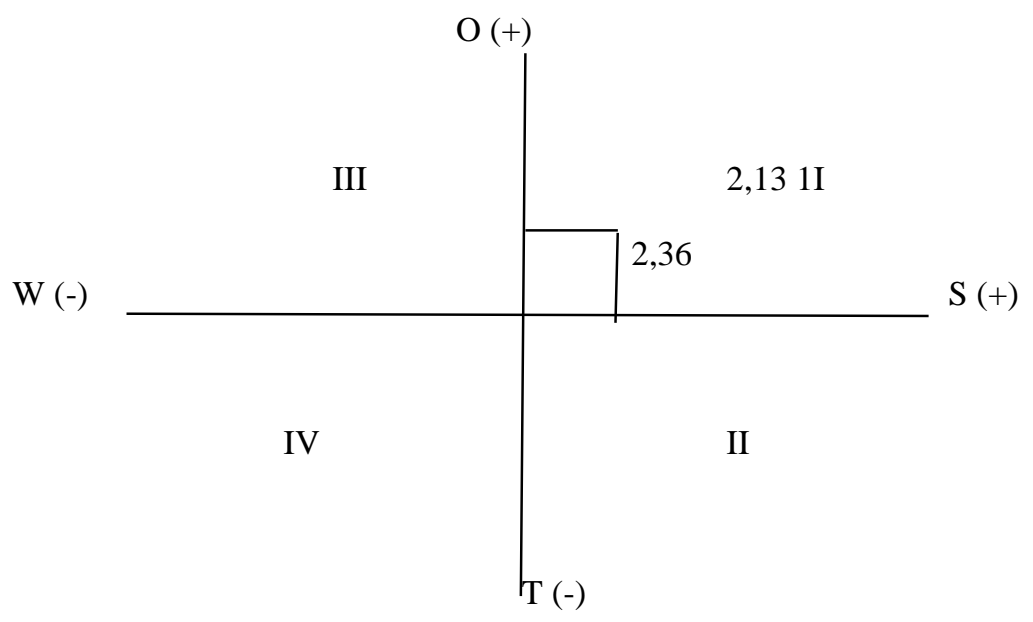

Hasil analisis ini menunjukan bahwa Obyek Wisata Alam Curug Ngelay berada pada kuadran I, artinya suatu kawasan wisata tersebut memiliki peluang dan kekuatan sehingga dapat memanfaatkan peluang yang ada. Berdasarkan hasil kuadran analisis SWOT maka strategi yang tepat untuk Pengembangan Obyek Wisata Alam Curug Ngelay adalah Strategi SO (Strength Opportunities). Startegi SO yaitu menciptakan strategi dengan menggunakan kekuatan yang dimiliki untuk memanfaatkan peluang.

\section{Perumusan Strategi Alternatif}

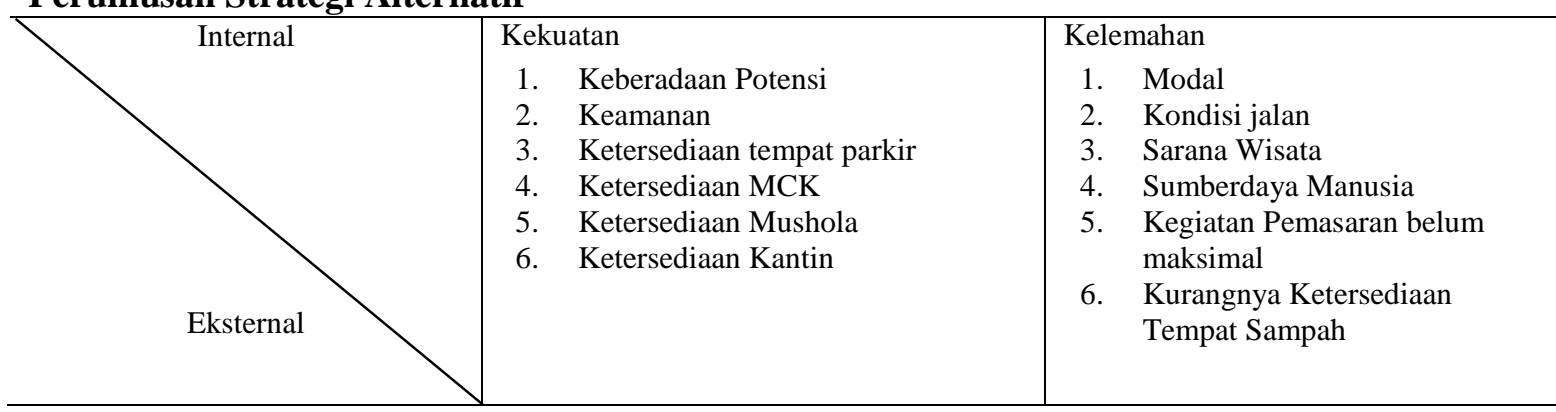

Analisis Matrik SWOT adalah yang menginteraksikan faktor strategis internal dan eksternal. Matrik ini dapat menggambarkan secara jelas bagaimana peluang dan ancaman (eksternal) yang dihadapi dapat disesuaikan dengan kekuatan dan kelemahan (internal) yang dimiliki. Analisis ini akan menghasilkan 4 buah alternatif strategi SO, WO, ST, SW.

Formulasi strategis bertujuan untuk menyusun strategi sesuai dengan kebijakan organisasi. Formulasi strategi harus dilakukan agar mampu menyelesaikan masalah baik saat ini maupun yang diprediksi akan terjadi dimasa datang. 


\begin{tabular}{|c|c|}
\hline Peluang & Strategi SO \\
\hline $\begin{array}{ll}\text { 1. } & \text { Meningkatnya Pendapatan } \\
& \text { Daerah } \\
\text { 2. } & \text { Dukungan Masyarakat } \\
& \text { Sekitar } \\
\text { 3. } & \text { Penambahan Fasilitas }\end{array}$ & $\begin{array}{l}\text { 1. Meningkatkan sara } \\
\text { 2. Meningkatkan kerja } \\
\text { masyarakat } \\
\text { 3. Mengembangkan se } \\
\text { dimiliki, bekerjas } \\
\text { pengelola, masya } \\
\text { pengunjung }\end{array}$ \\
\hline \begin{tabular}{ll}
\multicolumn{2}{l}{ Ancaman } \\
1. & PencemaranLingkungan \\
2. & Konflik Sosial Masyarakat \\
3. & Bencana alam
\end{tabular} & $\begin{array}{l}\text { Stategi ST } \\
\text { 1.Melakukan } \\
\text { himbauan/sanksi } \\
\text { bagi yang merusak } \\
\text { kawasan wisata } \\
\text { dan yang membuang } \\
\text { sampah sembaranga } \\
\text { 2. Meningkatkan peng } \\
\text { pengunjung }\end{array}$ \\
\hline \multicolumn{2}{|c|}{$\begin{array}{l}\text { SIMPULAN } \\
\text { Simpulan dalam penelitian ini sebagai } \\
\text { berikut: } \\
\text { 1. Potensi yang terdapat di Obyek Wisata } \\
\text { Alam Curug Ngelay terdapat beberapa } \\
\text { potensi diantaranta yaitu Bentang Alam, } \\
\text { Curug Ngelay serta terdapat } 7 \text { jenis } \\
\text { potensi Flora dan } 7 \text { jenis potensi Fauna. } \\
\text { 2. Berdasarkan faktor internal dan eksternal } \\
\text { Obyek Wisata Alam Berada pada kuadran } \\
\text { I artinya suatu kawasan wisata tersebut } \\
\text { memiliki peluang dan kekuatan sehingga } \\
\text { dapat memanfaatkan peluang dankekuatan } \\
\text { yang ada }\end{array}$} \\
\hline
\end{tabular}

\section{REFERENSI}

Ading. 2010. Studi Pengembangan Faktor Internal dan Eksternal Kawasan Wisata Alam Lembah Cilengkrang Kabupaten Kuningan (skripsi). Kuningan: Program Sarjana, Universitas Kuningan.

Aryanti, Nita Septi. 2013. Analisis Pengaruh Kualitas Sumber Daya Manusia terhadap Strategi Pemasaran dan
Strategi WO

1. Peningkatan SDM dengan memberikan pembinaan/ pelatihan

2. Menjalin/ membuka kerjasama dengan pihak lain

3.Meningkatkan kerjasama dengan masyarakat sekitar dalam upaya pengelolaan Kawasan

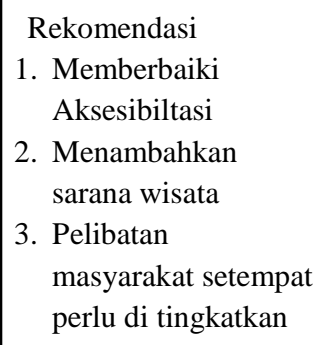
penyuluhan guna memberikan pemahaman pada masyarakat akanwisata alam dan manfaatnya

2. Mejaga kelestarian alam baik oleh pengunjung, pengelola maupun masyarakat.

Pelayanan di Desa Wisata Kebonagung

Imogiri Bantul (tugas akhir). Yogyakarta: Program Diploma III, Universitas Gadjah Mada

Asriandy, I.2016. Strategi Pengembangan Obyek Wisata Air Terjun Bissapu Di Kabupaten Bantaeng [Skripsi]. Universitas Hasanuddin. Makassar.

Darmawan, D. dan Fadjarajani, S. 2016. "Hubungan Antara Pengetahuan dan Sikap Pelestarian Lingkungan dengan Perilaku Wisatawan dalam Menjaga Kebersihan Lingkungan (Studi di Kawasan Objek Wisata Alam Gunung Galunggung Desa Linggajati Kecamatan Sukaratu Kabupaten Tasikmalaya)". Jurnal Geografi. 4 (1): Hal 37-49.

David, Fred R. Manajemen Strategi. Ed. Ke7. Konsep. Terjemahan. (Jakarta: PT. Indeks, 2004).

Doglas, R. W. 1978. Forest Recreation. Perganion FressInc, New York.

Fandeli, C. 2002. Perencanaan Kepariwisataan Alam. Fakultas Kehutanan Universitas Gajah Mada. Yogyakarta. 
Flamin, A. dan Asnaryati. 2013. Potensi ekowisata dan strategi pengembangan tahura nipa-nipa, kota Kendari, Sulawesi Tenggara. Jurnal Penelitian Kehutanan Wallacea. Vol. 2. No. 2. Forestry Department Faculty of Agriculture Haluoleo University. Hal $154-156$.

Jauch, L.R dan Glueck, W.F. , 1998 Manajemen Strategi dan Kebijakan Perusahaan. PT. Erlangga Jakarta.

Karyono, H. 1997. Kepariwisataan PT. Remaja Rosdakarya. Jakarta.

MackKinon, J.,K. MackKinon, G. Child dan J. Thorsel. 1990. Pengelolaan Kawasan yang Dilindungi di Daerah Tropika (Terjemahan). Gajah Mada University Press. Yogyakarta.

Meyers, Koen. 2009. Panduan Dasar Pelaksanaan Ekowisata. Jakarta: Technical Adviser for Environmental Sciences UNESCO.

Nova. 2000. Sistem Pengelolaan Wisata Alam. Gramedia Pustaka. Bandung.

Nuryani. 2003. Pengembangan Wisata Alam di Taman Wisata Plawangan Tugo [Skripsi]. Jurusan Konservasi Sumberdaya Hutan Fakultas Kehutanan. Bogor.

Priakusuma, S. 1993. Ekoturisme Sebagai Pengembangan Usaha Bidang Kehutanan dimasa mendatang. Duta Rimba, 161.

Ramdani, C. 2008. Strategi Pengembangan Wisata Alam Taman Nasional Gunung Gede Pangrango Cibodas Cianjur Jawa Barat [Skripsi]. Universitas Indonesia Negri Syarif Hidayatullah. Jakarta.

Rangkuti, Freddy. 2002. Analisis SWOT Teknik Membedah Kasus Bisnis.
Reorontasi Konsep Perencanaan Strategi Menghadapi Abad 21. PT Gramedia Pustaka Utama. Jakarta.

Sari, Y.A.M. 2009. Peran Promosi Dan Pemasaran DalamMeningkatkan Jumlah Wisatawan Di Objek Wisata Ndayu Alam Asri [Skripsi]. Surakarta: Universitas Sebelas Maret.

Sofia Nuraeni, B. 2014. "Analisis FaktorFaktor Yang Mempengaruhi Minat Kunjung Ulang Wisatawan Museum Ranggawarsita Semarang". Jurnal Bisnis Strategi. 23 (1): Hal 1-20.

Sugiyono. 2012. Metode Penelitian Administrasi. Alfabeta. Bandung.

Sugiyono. (2013).Metode Penelitian Kuantitatif, Kualitatif dan Kombinasi (Mixed Methods). Alfabeta. Bandung.

Suwantoro, G. 1997. Dasar - dasar Pariwisata. Andi, Jakarta.

Undang - Undang No 9 Tahun 1990. Tentang Kepariwisataan.

Wahab, S. 2003. Manajemen Kepariwisataan. Pradnya Paranita. Jakarta.

Yanto, I. 2010. Analisis Strategi Pengelolaan dan Pengembangan Obyek Wisata Bumi Perkemahan Palutungan Gunung Ciremai Kabupaten Kuningan (skripsi). Kuningan: Program Sarjana, Universitas Kuningan.

Zulhijja, L. dan Azzuhri, M. "Pengaruh Pelatihan dan Pengembangan Sumber Daya Manusia terhadap Organizational Citizenship Behavior dan Kinerja Pegawai pada Dinas Kebudayaan dan Pariwisata Kabupaten Kediri” Hal 1-14. 